\title{
Developmental Aspects of Figurative Expression according to Discourse Types in Writing of School- Aged Children
}

\author{
Hee-Sook Bae ${ }^{\mathrm{a}}$, Sunghee Park \\ ${ }^{a}$ Department of Speech-Language Therapy E Aural Rehabilitation, Woosong University, Daejeon, Korea \\ ${ }^{b}$ Department of Rehabilitation, Chonbuk National University Hospital, Jeonju, Korea
}

Correspondence: Sunghee Park, MD Department of Rehabilitation, Chonbuk National University Hospital, 20 Geonji-ro, Deokjin-gu, Jeonju 54907, Korea

Tel: $+82-63-250-1820$

Fax: +82-63-254-4145

E-mail: shpark0130@jbnu.ac.kr

Received: April 5, 2017

Revised: May 22, 2017

Accepted: May 31, 2017
Objectives: This study aims to analyze developmental aspects of figurative expression in discourses written by school-aged children, according to grade and type of discourses (descriptive and narrative), and to examine the correlation between figurative expression and length of discourse and diversity of words. Methods: Seventy-two typically developing children (2nd, 4th, and 6 th grade) were asked to write a descriptive discourse and a narrative discourse using the topics: 'My Friend' and 'Snow White'. Three subtypes of figurative language (simile, metaphor, and idiom) embedded in the written discourses were analyzed. The correlation between figurative expressions and discourse elements, such as length of discourse (T-unit, number of total words [NTW]) and lexical diversity (number of different words [NDT], value of NDW/T-unit [MLT-dw]), were analyzed. Results: As children's grade level increased, the usage rate of figurative expressions generally increased in their discourses. However, the increase varied according to the subtype of figurative expression and the type of discourse. In addition, figurative expressions and lexical diversity showed a positive correlation in both types of discourse. Conclusion: These findings indicate that discourse type and figurative type should be considered for evaluation of and intervention regarding figurative expression for school-aged language delayed children, and that intervention concerning figurative expression is worthwhile for strengthening their ability to make lexical and semantic connections.

Keywords: Figurative expression, Figurative language development, School-aged children, Descriptive discourse, Narrative discourse
비유언어는 문자적 언어, 외연적 언어와 대립되는 개념으로 "인 간의 인지능력을 가장 잘 보여주는 언어 형태이며 의미론의 최종 단계"(Park, 2000)라고 할 수 있다. 비유언어는 도구언어를 사용하 여 목표언어를 표현하는 방식을 취하는데, 그 방식에 따라 직유, 은 유, 관용어 등의 다양한 유형으로 나타난다. 직유가 '같이', '처럼' ‘듯과 같은 명시적 표지를 동반하여 목표언어와 도구언어를 직접 적으로 연결하는 데 비해, 은유는 특정 표지 없이 유사한 요소가 있거나 핵심적 요소를 공유한 도구언어를 통해 목표언어를 지시한 다. 관용어의 경우, 두 단어 이상이 모여 고정된 표현처럼 사용되면 서 구성 요소가 지닌 의미 조합과는 다른 의미를 지시한다.
의사소통 차원에서 비유언어는 발신자의 감정을 다양한 수사학 적 방식으로 담아내어 메시지 전달의 효과를 높이는 이른바 '표현 적 기능'(Jakobson, 1973)을 담당하며 사회적 상호작용에 활용되어 학교생활이나 사회생활을 위한 기술 획득에도 영향을 미친다고 보 고된다(Dickson, 2010). 또한, 비유언어는 개념적 층위를 활용하는 지식과도 밀접하게 관련되어 있어 어휘의 의미관계를 확장시키는 데에 관여한다고 주장된다(Lakoff \& Johnson, 2003). 즉, 비유언어 는 표현 기능을 통하여 의사소통의 폭을 넓혀줄 뿐 아니라 의미 구 조 및 층위에 영향을 미침으로써 언어 표현의 깊이를 한층 더해준 다고 하겠다. 
비유언어가 언제부터 발달하기 시작하는지 그 시점에 대해서는 의견이 다양하지만(Colston \& Kuiper, 2002), 일반적으로 학령전기 에 싹트고 학령기를 거쳐 청소년기까지 꾸준히 발달하면서 학업 수행 능력에 영향을 미치는 것으로 알려져 있다. 이러한 일련의 발 달 과정에서 가장 본격적인 비유언어 발달 시기는 학령기라고 할 수 있다. 사실, 학령기 동안 아동들은 읽기, 쓰기 같은 문어를 비롯 하여 상위언어와 담화 능력을 발달시키는데, 비유언어는 그 자체로 상위언어일 뿐 아니라 다른 상위언어 발달과도 연관이 있고(Van Kleeck, 1994), 학령기 문어 발달과도 깊은 연관성이 있다고 보고된 다(Cain, Twose, \& Knight, 2008; Hyun, Kim, \& Lim, 2011; Kim, 2012; Lee \& Kim, 2015; Song, 2012; Um, 2014). 따라서, 학령기 동 안 비유언어 발달이 지체되면 학령기뿐 아니라 그 이후의 언어발달 과 학업 성취에도 영향을 미칠 수 있는 만큼 학령기 아동의 비유언 어 발달 양상을 파악할 필요가 있다.

학령기 언어발달에서 비유언어가 갖는 중요성이 인식되면서 비 유언어 연구가 더욱 활발해지고 있으나, 자폐스펙트럼장애, 지적장 애, 단순언어장애 같은 다양한 장애군이나 학령기 읽기부진 아동 등을 대상으로 한 연구가 주를 이루고 있다(Hong \& Yim, 2014; Jeong, 2012; Kim, Nam, \& Kwon, 2012; Lee, Bae, \& Lee, 2016; Lee \& Kim, 2015; Lee, Ko, Hwang, 2014; Lim, 2010; Vogindroukas \& Zikopoulou, 2011; Yi, Hwang, \& Lim, 2013). 정상발달을 보이는 일 반 아동의 비유언어 발달 연구는 상대적으로 드문 편이고, 그마저 도 비유언어 이해력 발달에 집중되는 경향이 있다(Billow, 1975; Byun \& Choi, 2000; Chung, 2002; Kim, 2002; Nippold \& Haq, 1996; Nippold, Taylor, \& Baker, 1996; Nippold \& Taylor, 1995; Nippold, 1985). Traylor (1996)가 지적한 것처럼 비유언어를 이해하고 해석 하는 능력에서 나아가 이를 사용할 줄 알아야 하지만 표현에 초점 을 맞춘 비유언어 연구는 Sweet (1974)나 Lee (2011) 같은 몇몇 연구 를 제외하고는 찾아보기 힘들 정도로 매우 제한적이다. Sweet (1974) 는 $4,5,6$ 학년 아동을 대상으로 이야기(tale), 묘사(description), 시 (poetry)와 같은 여러 장르의 글쓰기를 통해 비유언어를 분석하여, 고학년 아동들이 가장 많이 사용한 비유언어가 직유, 은유, 과장 순이고, 글을 잘 쓰는 아동의 가장 큰 특징이 비유언어 사용이었다 고 보고한 바 있다. Lee (2011)는 2, 4, 6학년 한국 아동의 산문과 운 문 쓰기 자료에 나타난 은유 표현 빈도와 은유 유형별 양상을 분석 하였다. 한편, Naylor와 Van Herwegen (2012)은 일반 아동을 연구 의 중심 대상으로 삼지는 않았으나 윌리엄스증후군 아동의 이야기 담화에 나타나는 비유언어 산출 양상을 분석하기 위해 정상발달 아동의 비유언어를 함께 다루었다.

일반 아동의 비유언어 표현에 대한 이와 같은 선행연구를 살펴보
면, 글의 장르에 따라 비유언어 유형별 표현 양상을 분석한 Sweet (1974)의 연구는 고학년 아동만을 대상으로 하여 저학년에서 고학 년을 관통하는 발달 양상을 파악하기 어렵다는 점이 있고, $2,4,6$ 학 년 아동의 비유언어 표현을 분석한 Lee (2011)의 연구는 여러 비유 유형 중에서 은유만을 다루어 전반적인 비유언어의 사용 양상을 파악하기 어렵다. 따라서 일반 아동의 비유언어 표현 능력이 전반적 으로 어떠한 발달 양상을 보이는지 파악하기 위해서는 좀 더 다양 한 유형의 비유 표현 발달 정보가 필요하다. 또한 비유언어는 문맥 안에서 다루어져야 한다는 특징을 갖는 만큼(Cain, Oakhill, \& Lemmon, 2005), 단편적 문장이 아니라 자연스럽게 문맥을 제시할 수 있는 담화를 통하여 다룰 필요가 있다. 특히, Sweet (1974)의 언 급처럼 글쓰기 장르에 따라 문체가 달라지고 문체에 따라 비유 유 형별 사용 양상이 달라질 수 있으므로, 담화유형에 따른 비유 유형 별 사용 양상을 살펴볼 필요가 있다.

이에, 본 연구는 학령기 일반 아동을 대상으로 담화 쓰기 검사를 실시하고 이들의 글쓰기에 나타난 비유언어(직유, 은유, 관용어) 표 현이 담화유형(묘사담화, 이야기담화)과 학년 $(2,4,6)$ 에 따라 어떠 한 양상을 보이는지 분석하고자 하였다. 또한 본 연구는 여러 담화 유형 중에서 묘사담화(descriptive discourse)와 이야기담화(narrative discourse)에 초점을 맞추었다. 이는 설명담화가 초등학교부터 청소년기에 걸쳐 발달하고 논쟁담화가 청소년기에 발달하는 데 비 해, 묘사담화와 이야기담화는 주로 초등 학령기 동안 발달한다고 보고되기(Bae, 2016b; Kuczaj \& McClain, 1984; MacSaveny, 2010) 때문이다. 묘사담화가 사람, 사물, 장소 등과 같은 대상을 소개하거 나 특성을 기술하여 독자가 그 대상을 떠올릴 수 있도록 한다면 (Bae, 2016b) 이야기담화는 일련의 사건을 진술하여 전달하는 방식 을 취하기 때문에 글의 장르에 따른 문체 차이가 두 담화유형 비교 를 통해잘 드러날 수 있다고 판단되기 때문이다.

본 연구는 수집한 담화를 최소종결단위인 T-unit (minimally terminable unit)으로 분석한 후, 각 비유언어(직유, 은유, 관용어) 의 사용 빈도를 T-unit에 대한 비율로 측정하였다. 또한, 비유언어 가 어휘 확장에 영향을 미친다는 Dickson (2010)의 보고나 개념체 계 내에서의 의미 간 계층 관계, 즉 어휘의 의미 층위를 확장시키는 데에 영향을 미친다는 Lakoff와 Johnson (2003)의 주장에 근거하 여 비유언어 사용 비율, 즉 비유 표현 비율이 담화 쓰기에서 담화길 이나 어휘다양도와 어떠한 상관관계를 보이는지 파악하고자 하였 다. 이를 위하여, 담화길이는 전체 낱말 수(number of total words, NTW)와 T-unit 수로 분석하였고, 어휘다양도는 서로 다른 낱말 수(number of different words, NDW)와 T-unit에 대한 서로 다른 낱말 수의 비율인 MLT-dw (NDW/T-unit)로 측정하여 분석하였다. 
이와 같은 연구는 담화유형과 학년에 따른 비유표현 발달 추이 에 대한 기초 정보를 제공할 뿐 아니라, 학령기 아동의 비유언어 지 도를 위한 활동 및 자료 선정, 나아가 언어발달이 지체된 학령기 아 동의 비유언어 평가 및 중재에도 활용될 수 있을 것이다.

본 연구의 연구문제는 다음과 같다.

첫째, 학령기 아동의 비유언어(직유, 은유, 관용어) 사용 비율은 담화유형(묘사담화, 이야기담화)과 학년 $(2,4,6)$ 에 따라 어떠한 양 상을 보이는가?

둘째, 학령기 아동의 비유언어 사용 비율은 담화길이나 어휘다 양도와 어떠한 상관관계를 보이는가?

\section{연구방법}

\section{연구대상}

본 연구는 서울의 일반 초등학교에 다니는 학령기 $2,4,6$ 학년 아 동을 대상으로 하였다. 대상 아동들은 해당 초등학교의 일반학급 아동 중 (1) 1 학기 국어 단원 평가와 2 학기 국어 단원평가에서 모두 70점 이상을 획득하였고(Appendix 1), (2) 교사에 의해 학습과 또 래관계에 어려움이 없다고 보고되었으며, (3) 특별한 신체적, 정신 적, 정서적, 행동적 장애로 진단받은 경험이 없고, (4) 정서, 행동, 언 어 등의 영역에서 특수교육이나 치료를 받은 경험이 없는 것으로 보고되었다. 대상 아동에 대한 담화 쓰기검사는 2 학기 단원평가 일 주일 후에 이루어졌으며, 본 연구에 참여한 아동의 수는 총 72 명이 다. 참여 아동에 대한 기본정보는 Table 1에서 제시된 바와 같다.

\section{검사 도구 및 절차}

대상 아동은 두 가지 유형의 담화 쓰기에 참여하였다. 먼저, 묘사 담화와 이야기담화의 주제를 선정하기 위해 5 년 이상의 경력을 가 진 초등학교 교사 10 명을 대상으로 조사를 실시하였다. 묘사담화 주제를 위해서는 선행연구를 참고하여(Reed, 2012) 5 개의 주제('우 리엄마', '내 친구' 등)를 제시하였고, 이야기담화를 위해서는 세 개 의 인터넷 서점에서 공통적으로 제시하는 저학년 고전문학 권장도 서목록 중 상위에 해당하는 10 개의 동화 제목('미운아기오리', '백 설공주, '헨젤과 그레텔' 등)을 제시하였다. 전 학년 아동이 같은 주

Table 1. Information of participants

\begin{tabular}{lcc}
\hline & Mean age $(\mathrm{mo})$ & Gender $($ boy:girl) \\
\hline 2th grade $(\mathrm{N}=24)$ & 96.64 & $11: 13$ \\
4th grade $(\mathrm{N}=24)$ & 124.17 & $13: 11$ \\
6th grade $(\mathrm{N}=24)$ & 147.04 & $15: 9$ \\
Total $(\mathrm{N}=72)$ & 122.62 & $39: 33$ \\
\hline
\end{tabular}

제로 글쓰기를 할 경우 친숙도와 적합도가 높은 주제가 무엇인지 질문하여 가장 많은 교사가 선택한 '내 친구'와 '백설공주’를 묘사 담화와 이야기담화 쓰기의 주제로 선정하였다.

주제 선정 후 $\mathrm{A} 4$ 크기의 검사지를 준비하였다. 검사지 상단에 제 목으로 주제를 제시하고, 하단에 학년과 생년월일을 기재할 수 있 도록 하였다. 검사는 평일 아침 자습시간을 이용하여 조용한 교실 에 학년별로 따로 모여 진행되었다. 먼저 '내 친구’를 주제로 묘사담 화 쓰기를 진행하였고, 하루 뒤인 다음날 아침에 동일한 시간과 장 소에서 '백설공주'를 주제로 이야기담화 쓰기를 진행하였다.

검사자는 먼저 검사지를 배포하고 학년과 생년월일을 기재할 수 있도록 안내하였다. 모든 아동이 기재하였는지 확인한 후 아동들 에게 "이제부터 글쓰기를 할 거예요. 이건 시험이 아니니까 정성껏 쓰면 돼요. 다 쓰면 조용히 손을 들어 주세요.”라고 안내한 후, 각자 검사지에 제목으로 제시된 주제어를 읽어보고 1 분 동안 생각할 시 간을 가진 후 내용을 쓰도록 하였다. 쓰기검사는 시간 제한을 두지 않았으나 모든 아동이 최대 20 분을 넘지 않았다.

\section{자료분석}

비유언어(직유, 은유, 관용어)

본 연구는 비유언어 표현을 분석하기 위하여 학령기 아동의 묘 사담화 및 이야기담화에서 가장 빈번하게 나타나는 비유언어 유형 인 직유, 은유, 관용어를 분석 대상으로 삼았다.

직유의 경우, '같이', '처럼' 등의 조사나 '같다', '만큼이다' 등의 서 술적 표현을 동반하는데(Kim \& Jeon, 2013), 실제로 아동들은 담 화에서 “엄마같이”, “귀신처럼”, “보름달처럼” "조약돌같이” 등의 직유적 표현을 빈번히 사용하였다(Appendix 2). 반면, 은유는 직유 처럼 특정 표지를 사용하지 않고 목표언어와 유사성이 있거나 핵심 적 요소를 공유하는 도구언어를 통하여 비유하며 < $\mathrm{A}$ 는 A'다>와 같은 기본형식을 취한다. 본 연구에서는 Park (2000)의 은유 유형 분류에 근거하여 “내 친구는 호랑이 형님이다"와 같이 < $\mathrm{A}$ 는 A'다> 식의 전형적인 형식을 취하지 않더라도 "(내 친구는 요즘) 마술에 빠져 있습니다”와 같은 표현이나 “깊은 잠(에서 살아나다)” 같은 표 현도 은유로 분석하였다(Appendix 2). 관용어의 경우, 두 낱말 이 상으로 구성된 구나 절이 마치 하나의 고정된 표현처럼 사용되면서 이를 구성하는 요소의 의미적 조합과는 다른 의미를 지시한다. 예 를 들어, 대상 아동들의 담화에는 "거리가 멀다", "세상을 떠나서", "막을 내리다" 등의 관용어가 나타나는데, 이 표현들은 문자적 의 미를 넘어 친구와 나의 '관계', 백설공주 어머니의 '죽음, 이야기의 '끝'을 의미하는 것이다(Appendix 2).

한편, 관용어는 하나의 고정된 표현처럼 기능한다는 특성을 지 
니고 있어 은유와는 확연한 차이를 보이고 그 구분도 분명할 것 같 으나, 실제로는 관용어를 구성하는 단어 자체가 은유적이거나 은 유적 표현이 단어의 범위를 넘어 구로 표현되는 경우가 있어 분석 과정에서 은유와 관용어를 구분하기 어려운 경우가 있었다. 이에, 본 연구에서는 Moon (1996), Choi (2010) 등의 선행연구에서 제시 된 관용어와 은유의 목록에 근거하여 표현의 고정성 여부를 은유 와 관용어를 구분하는 기준으로 삼았다. 예컨대, "마술에 빠지다" 의 ‘빠지다’는 그 앞의 ‘마술' '책' '사랑' 등 얼마든지 다양한 단어 들이 조합 가능하므로 '마술'과 '빠지다'의 표현 고정성이 낮아 은 유성에 초점이 있다고 간주하고 은유로 처리하였다. 그러나 "입이 무겁다”의 경우 은유적이지만 ‘입’ 대신 '발' '어깨' 등으로 단어를 대치할 경우 그 의미가 달라지므로 조합 가능한 단어가 제한되고 표현이 고정되었다고 판단하여 은유적 관용어로 처리하였다.

\section{담화길이(T-unit, NTW)와 어휘다양도(NDW, NDW/T-unit)}

최소종결단위인 T-unit은 주절과 주절에 종속된 절로 구성된 단 위(Hunt, 1965)로, 일반적인 분석 기준에 따라 종속절은 주절과 함 께 하나의 단위로 분석하고 주어와 서술어 관계를 갖춘 등위절은 각각의 단위로 분할하였다. 다만, 주어가 빈번히 생략되는 한국어 의 특성을 고려하여 주어 생략이 자연스러우면 하나의 T-unit으로 간주하고, 하나의 주어에 여러 개의 서술어가 연결된 경우는 하나 의 T-unit에 포함시켜 분석하였다(Pae, Kwon, \& Jin, 2009). NTW 는 담화를 구성하는 모든 단어의 수로 측정하였고, 학교문법에 따 라 조사는 개별 단어로 분석하였으나 어미는 단어로 처리하지 않 았다. 복합어는 국립국어원의 “표준국어대사전"에 근거하여 표제 어로 등록된 경우만 하나의 단어로 처리하고 표제어 등록이 안 되 어 있는 경우는 각각의 구성 요소로 분할하여 처리하였다. 한편, 어 휘다양도 측정을 위해 가장 많이 사용되는 것은 TTR이라고 할 수 있다. 그러나 "TTR은 글의 길이가 길어질수록 기능어가 반복되기 때문에 그 비율이 낮아지는 경향이 있다"(Bae, 2016a). 본 연구는 학령기 $2,4,6$ 학년 아동을 대상으로 하기 때문에 학년에 따라 글의 길이가 달라지는데 대상 아동의 글을 동일한 길이로 통제하기 어려 웠다. 이에, 본 연구는 어휘다양도의 경우, NDW를 측정한 후 이를 T-unit에 대한 비율로 분석하였다.

\section{신뢰도}

비유언어 분석과 함께 담화길이와 어휘다양도 분석은 모두 주 연구자에 의해 이루어졌다. 1 차 분석 후 참여자별, 변인별로 재검토 되었다. 또한 연구자 간 신뢰도를 측정하기 위하여 은유 분석 및 담 화 분석의 경험이 있는 문학박사 1 인에게 비유언어 분석 기준을 제
시하고 자료의 $10 \%$ 에 해당하는 7 명의 자료를 분석하도록 한 후 연 구자의 분석 자료와 비교하였다. 1 차 비교에서 비유언어는 $93.33 \%$, 담화길이 및 어휘다양도는 $94.29 \%$ 의 일치도를 보였다. 불일치 부 분에 대해 논의 및 수정 후 $100 \%$ 일치도를 보였다. 또한 자료의 내 적 일치도를 확인하기 위해 Cronbach 알파를 구하였을 때 비유언 어 절대빈도에 대한 알파 값은 .753이었고 NTW와 NDW의 빈도에 대한알파 값은 835 였다.

\section{자료의 통계적 처리}

담화유형 및 학년에 따른 변인의 차이를 비교하기 위해 이원다변 량 분산분석을 실시하였다. 해석 과정에서 좀더 상세한 담화 내부 의 변화를 확인하기 위하여 각 담화유형 내에서 학년 간 차이에 대 한 유의성을 검토할 경우 일원배치 분산분석을 사용하였다. 또한 비유 표현 비율이 담화길이나 어휘다양도와 어떠한 상관관계를 보 이는지 파악하기 위해서는 피어슨 상관계수를 분석하였다. 본 연구 의 자료는 SPSS 18.0 프로그램을 사용하여 처리하였다.

\section{연구결과}

\section{담화유형 및 학년에 따른 비유언어 사용 양상}

본 연구는 담화유형(묘사담화, 이야기담화)과 학년 $(2,4,6)$ 이 비 유언어(직유, 은유, 관용어) 사용에 미치는 효과를 검정하고자 이 원다변량 분산분석을 실시하였다. 기술통계와다변량 분산분석 결 과는 Tables 2 와 3 에 제시된 바와같다.

전체적인 비유언어 사용 비율의 경우, 담화유형의 주효과가 나타 나지 않았으나 학년의 주효과는 나타났다 $\left(F_{(2,138)}=20.936, p<.001\right)$. 또한 담화유형과 학년의 상호작용효과는 나타나지 않았다. 이는 비 유 표현 비율이 학년 간 유의한 차이를 보이며 증가하였고, 이러한 증가 양상이 두 담화유형에서 유사하게 나타났음을 의미한다.

Table 2. Figurative expression rates

\begin{tabular}{lcccc}
\hline & $\begin{array}{c}\text { Figurative/ } \\
\text { T-unit }\end{array}$ & $\begin{array}{c}\text { Simile/ } \\
\text { T-unit }\end{array}$ & $\begin{array}{c}\text { Metaphor/ } \\
\text { T-unit }\end{array}$ & $\begin{array}{c}\text { Idiom/ } \\
\text { T-unit }\end{array}$ \\
\hline $\begin{array}{l}\text { Descriptive type } \\
\text { 2nd grade }\end{array}$ & $0.093(0.131)$ & $0.004(0.018)$ & $0.033(0.068)$ & $0.056(0.089)$ \\
4th grade & $0.193(0.127)$ & $0.035(0.070)$ & $0.091(0.080)$ & $0.067(0.076)$ \\
6th grade & $0.286(0.218)$ & $0.040(0.053)$ & $0.147(0.101)$ & $0.099(0.125)$ \\
Narrative type & & & & \\
2nd grade & $0.084(0.126)$ & $0.035(0.093)$ & $0.035(0.053)$ & $0.014(0.033)$ \\
4th grade & $0.173(0.120)$ & $0.030(0.074)$ & $0.085(0.099)$ & $0.058(0.081)$ \\
6th grade & $0.288(0.149)$ & $0.012(0.034)$ & $0.133(0.095)$ & $0.143(0.087)$ \\
\hline
\end{tabular}

Values are presented as mean (SD). 
Table 3. MANOVA of discourse types and grades for variables

\begin{tabular}{lcccc}
\hline Variable & SS & df & MS & $F$ \\
\hline Text types & & & & \\
Figurative/T-unit & .004 & 1 & .004 & .158 \\
Simile/T-unit & .000 & 1 & .000 & .009 \\
Metaphor/T-unit & .001 & 1 & .001 & .181 \\
Idiom/T-unit & .000 & 1 & .000 & .034 \\
Grade & & & & \\
Figurative/T-unit & .929 & 2 & .464 & $20.936^{* * *}$ \\
Simile/T-unit & .004 & 2 & .002 & .550 \\
Metaphor/T-unit & .267 & 2 & .133 & $18.772^{* * *}$ \\
Idiom/T-unit & .184 & 2 & .092 & $12.390^{* * *}$ \\
Text types $\times$ Grade & & & & \\
Figurative/T-unit & .003 & 2 & .001 & .057 \\
Simile/T-unit & .021 & 2 & .011 & 2.721 \\
Metaphor/T-unit & .002 & 2 & .001 & .106 \\
Idiom/T-unit & .045 & 2 & .023 & $3.059^{*}$ \\
\hline
\end{tabular}

${ }^{*} p<.05,{ }^{* * *} p<.001$.

비유언어 하위 유형별로 살펴보면, 직유의 경우 담화유형의 주효 과도, 학년의 주효과도 나타나지 않았다. 담화유형과 학년의 상호 작용효과도 나타나지 않았다. 묘사담화에서는 2 학년에서 4,6 학년 으로 올라가면서 사용 비율이 증가하고 이야기담화에서는 학년이 올라감에 따라 오히려 그 사용 비율이 감소하였음에도 불구하고 담화유형의 주효과나 상호작용효과가 나타나지 않은 것은 학년에 따른 직유 사용 양상이 두 담화유형에서 역현상을 보임으로써 상 쇄효과가 나타났기 때문으로 해석된다.

은유의 경우, 담화유형의 주효과는 나타나지 않았으나, 학년의 주효과가 나타났다 $\left(F_{(2,138)}=18.772, p<.001\right)$. 담화유형과 학년의 상호작용효과는 나타나지 않았다. 이는 학년이 올라감에 따라 은 유의 사용 비율이 학년 간 유의한 차이를 보이며 증가하였고, 이러 한 추세가 묘사담화와 이야기담화 모두에서 유사하게 나타났음을 의미한다.

관용어의 경우, 담화유형의 주효과는 나타나지 않았으나, 학년의 주효과와 $\left(F_{(2,138)}=12.390, p<.001\right)$, 담화유형과 학년의 상호작용효 과가 나타났다 $\left(F_{(2,138)}=3.059, p<.05\right)$. 학년의 주효과가 나타난 것 은 학년이 올라감에 따라 관용어 사용 비율이 유의하게 높아졌기 때문이며, 상호작용효과가 나타난 것은 학년에 따른 관용어 사용 양상이 두 담화유형에서 다르게 나타났기 때문으로 해석된다(Figure 1). 한편, 관용어 사용 양상이 담화유형에 따라 달랐음에도 불 구하고 담화유형의 주효과가 나타나지 않은 것은 저학년에서는 묘 사담화에서 사용 비율이 높고 고학년에서는 이야기담화에서 사용 비율이 높았기 때문으로 해석된다.

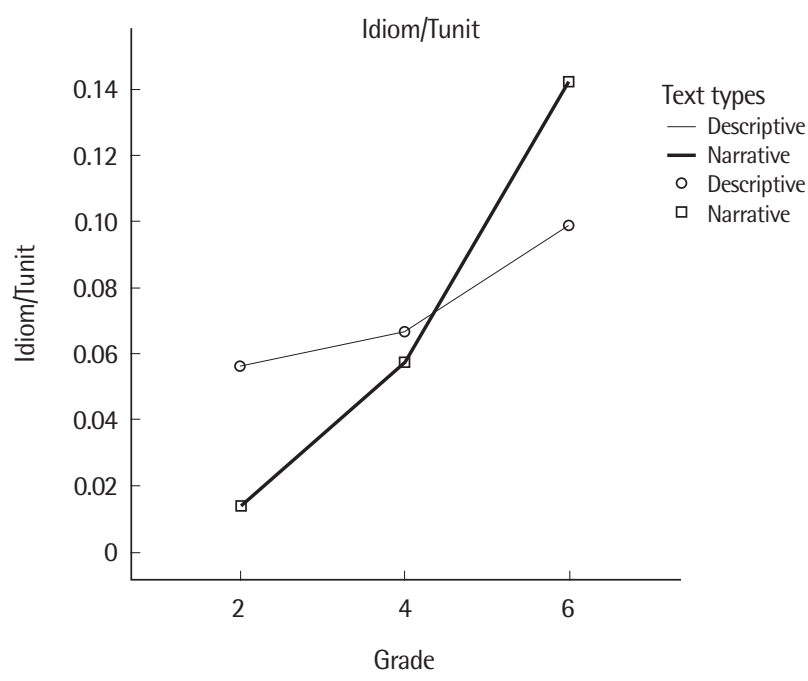

Figure 1. Figurative expressions.

이러한 결과가 어느 학년 구간에서 비롯되는지 확인하고자 사후 분석을 실시하였다. 먼저, 전체 비유 표현 비율의 경우, 2-4, 4-6, 2-6 모든 대응 구간에서 유의한 차이가 나타나 전체적인 비유 표현 비 율은 모든 학년 대응 구간에서 뚜렷한 증가를 보였다. 반면, 직유는 2-4, 2-6, 4-6 학년 대응에서 유의한 차이가 전혀 나타나지 않았는 데, 이는 학년에 따른 상승 곡선을 보인 묘사담화와 학년에 따른 하 강 곡선을 보인 이야기담화의 상쇄효과 때문이다. 은유는 2-4, 2-6, 4-6학년의 대응 비교에서 모두 유의한 차이를 보여 학년마다 뚜렷 한 증가가 나타났음을 알 수 있다. 관용어는 2-6, 4-6학년 구간에서 유의한 차이를 보였는데, 이는 고학년인 4학년에서 6학년으로 올라 가면서 두드러진 증가 추세를 보였음을 의미한다.

본 연구는 각 담화유형 내에서 학년에 따른 비유 표현 비율의 변 화도 살펴보았다. 일원배치 분산분석 결과, 묘사담화에서는 전체 비유 표현 비율을 비롯하여 직유와 은유가 모두 학년에 따른 유의 한 변화를 보였다. 반면, 관용어 비율은 학년에 따른 유의한 변화가 나타나지 않았다. 사후분석 결과, 직유와 은유는 2-4학년 간 유의 한 변화가 나타났다. 반면 관용어는 어느 학년 구간에서도 유의한 변화가 없었다. 이러한 결과는 묘사담화의 경우, 2 학년에서 4 학년 으로 올라가면서 직유와 은유 비율이 높아졌고 4-6학년 간 변화는 나타나지 않아, 대체로 비유 표현이 저학년에서 고학년으로 가면서 뚜렷하게 증가하는 추세를 보였음을 의미한다.

이야기담화의 경우, 은유와 관용어 표현 비율이 학년이 올라감 에 따라 유의한 차이를 보이며 증가하였으나, 직유는 그렇지 않았 다. 사후분석에서, 직유는 어느 구간에서도 유의한 변화가 나타나 지 않았다. 은유는 2-6학년에서 유의한 변화가 나타났고, 관용어는 
Table 4. Pearson coefficients

\begin{tabular}{|c|c|c|c|c|c|c|c|c|c|c|c|c|}
\hline & \multicolumn{3}{|c|}{ Figurative/T-unit } & \multicolumn{3}{|c|}{ Simile/T-unit } & \multicolumn{3}{|c|}{ Metaphor/T-unit } & \multicolumn{3}{|c|}{ Idiom/T-unit } \\
\hline & $D$ & $\mathrm{~N}$ & T & D & $\mathrm{N}$ & $\mathrm{T}$ & D & $\mathrm{N}$ & T & D & $\mathrm{N}$ & $\mathrm{T}$ \\
\hline T-unit & .042 & 0.01 & .013 & .027 & .046 & .033 & .063 & .148 & .031 & 118 & .175 & .030 \\
\hline NTW & $.254^{*}$ & .171 & $.205^{*}$ & .126 & .039 & .070 & $.205^{*}$ & .016 & .081 & .199 & $.285^{*}$ & $.239 * *$ \\
\hline NDW & $.466^{* * *}$ & .195 & $.327^{* * *}$ & .163 & .068 & .104 & $.419^{* * *}$ & .024 & $.213^{*}$ & $.356^{* *}$ & $.260^{*}$ & $.300 * * *$ \\
\hline MLT-dw & $.683^{* * *}$ & $.354^{* *}$ & $.495^{* * *}$ & $.266^{*}$ & .144 & $.184^{*}$ & $.480^{* * *}$ & $.393^{* *}$ & $.410^{* * *}$ & $.635^{* * *}$ & .090 & $.350^{* * *}$ \\
\hline
\end{tabular}

$\mathrm{D}=$ descriptive discourse; $\mathrm{N}=$ narrative discourse; $\mathrm{T}=$ total; $\mathrm{T}$-unit= minimally terminable unit; $\mathrm{NTW}=$ number of total words; $\mathrm{NDW}=$ number of different words; $\mathrm{MLT}-\mathrm{dw}=\mathrm{value}$ of NDW/T-unit.

${ }^{*} p<0.05,{ }^{* *} p<0.01,{ }^{* * *} p<0.001$.

2-6, 4-6학년 간 뚜렷한 변화를 보였다. 즉, 직유는 학년에 따른 유 의한 변화가 없었고, 은유는 저학년에서 고학년으로 올라가면서 증 가한 후 증가추세가 완화되었으며, 관용어는 고학년 내에서 뚜렷하 게 증가하였음을 보여준다.

\section{비유언어와 담화요소의 상관관계}

비유언어가 담화길이나 어휘다양도 같은 담화요소와 어떠한 상 관관계를 나타내는지 파악하고자 담화 전체와 각각의 담화 내에서 변인 간 Pearson 상관계수를 분석하였다(Table 4). 전체 비유 표현 을 비롯하여 직유, 은유, 관용어의 비율은 전반적으로 T-unit이나 NTW 같은 담화길이 요소보다는 NDW나 MLT-dw 같은 어휘다 양도와 상관관계가 높았다. 특히, MLT-dw와의 상관관계가 가장 높았다. 예컨대, 직유의 경우 T-unit, NTW, NDW와 유의한 상관관 계가 전혀 나타나지 않았음에도, MLT-dw와의 상관관계는 유의했 다. 이러한 현상은 두 가지 유형의 담화에서 공통적으로 나타났다.

\section{논의 및 결론}

본 연구는 학령기 일반 아동의 담화 쓰기에 나타난 비유언어 사 용 비율이 담화유형 및 학년에 따라 어떠한 양상을 보이는지, 담화 길이나 어휘다양도와의 상관관계는 어떠한지 살펴보고자 하였다.

직유의 경우, 담화유형의 주효과나 학년의 주효과가 나타나지 않 았다. 상호작용효과도 나타나지 않았다. 담화유형의 주효과나 상호 작용 효과가 나타나지 않은 것은 묘사담화에서 직유 비율의 상승 곡선과 이야기담화에서의 하강 곡선이 담화유형 간 상쇄효과로 이 어졌기 때문으로 해석된다. 또한, 학년의 주효과가 나타나지 않은 것은 직유 사용 능력의 발달 시기와 관련이 있을 것으로 해석된다. 직유는 비유적 특성을 그대로 간직하면서도 명시적 표지를 사용함 으로써 은유나 관용어와 같은 다른 비유언어에 비해 일찍 발달하 는 편이다(Seidenberg \& Bernstein, 1988). 따라서 이미 직유 표현을 자유자재로 사용할 수 있게 된 학령기 아동의 경우, 양적인 특성만
으로는 그 발달적 양상을 파악하기 어려울 수 있다. 이러한 결과는 5 세에 이르면 직유의 하위유형이나 오류 유형에 따른 이해도 차이 가 사라졌다는 선행연구(Kim \& Jeon, 2013) 결과나, 고학년 아동이 여러 유형의 글쓰기에서 가장 많이 사용한 비유언어가 직유였지만 5 학년에서 6학년으로 올라가면서는 직유 표현이 뚜렷하게 증가하 지 않았다는 선행연구(Sweet, 1974) 결과와도 맥을 같이 한다.

은유의 경우, 담화유형의 주효과는 나타나지 않았으나 학년의 주효과는 나타났다. 담화유형과 학년의 상호작용효과도 나타나지 않았다. 이는 은유 표현 비율이 학년이 올라갈수록 유의하게 증가 하였으며, 이러한 양상이 두 담화유형에서 크게 다르지 않았음을 의미한다. 사후분석에 따르면, 담화 전체에서는 2-4, 2-6, 4-6학년 모든 구간에서 유의한 차이가 나타났으나 각 담화 내에서는 2-6학 년 간 차이만 유의한 것으로 나타났다. 이와 같은 결과는, 각 담화 에서 유의 수준에 이르지 않았던 학년 간 차이가 누적되어 담화 전 체에서는 두드러진 차이로 이어졌기 때문으로 해석된다. 이는 학령 기 아동의 은유 비율 증가 곡선이 담화 크기에 따라 기울기는 다소 달라질 수 있어도 전반적으로는 학년에 따라 상승하는 양상을 보 인다는 것을 의미한다. 또한, 전체 담화에서 은유 비율이 2-4, 4-6 학년에서 뚜렷한 증가 양상을 보였다는 본 연구의 결과는, 은유 이 해 능력이 9-12세 사이에 뚜렷하게 증가했다고 보고한 선행연구 (Winner, Rosenstiel, \& Gardner, 1976)나, 고학년에서 뚜렷하게 은 유 능력이 발달했다는 선행연구(Nippold, 1985; Siltanen, 1990)의 주장과도 맥을 같이 한다고 할 수 있다. 한편, 학년에 따라 은유 사 용 비율이 뚜렷한 상승 곡선을 그린다는 본 연구의 결과는 은유가 어휘의 의미 층위와 관련이 있다는 주장(Lakoff \& Johnson, 2003) 에 근거할 때 학령기 동안 어휘 의미 층위도 그만큼 심화된다는 것 을 예측하게 한다.

관용어 분석에서 담화유형의 주효과는 나타나지 않았으나, 학년 의 주효과와 담화유형과 학년의 상호작용효과가 모두 나타났다. 담 화유형의 주효과가 나타나지 않은 것은 두 담화유형에서 관용어 사용 양상이 학년 간 상쇄효과를 보였기 때문이며, 학년의 주효과 
가 나타난 것은 학년이 올라감에 따라 관용어 사용 비율이 뚜렷한 차이를 보이며 증가하였음을 의미한다. 또한, 담화유형과 학년의 상호작용효과는 두 담화유형에서 학년에 따른 관용어 발달 양상 이 유의하게 달랐기 때문으로 해석된다. 학년에 대한 사후분석을 실시하였을 때, 묘사담화에서는 학년 간 차이가 전혀 나타나지 않 았지만, 이야기담화에서는 4-6, 2-6학년 간에 유의한 차이가 나타 났고, 담화 전체에서는 2-4, 4-6, 2-6학년 간 차이가 모두 유의한 것 으로 나타났다. 이는 전체 담화에서 관용어에 대한 학년의 주효과 가 주로 이야기담화에 의해 주도되었음을 의미한다. 특히, 6 학년에 서의 관용어 비율 증가가 매우 두드러졌다. 이러한 결과는 관용어 발달 곡선이 학령기 이후에도 지속적으로 상승될 것임을 시사하 는데, 이는 11,12 세에도 관용어가 여전히 충분히 발달하지 않았다 는 선행연구(Cain et al., 2008)의 보고와도 맥을 같이하는 것이다.

6학년의 관용어 사용 빈도가 이야기담화를 중심으로 두드러지 게 증가한다는 본 연구의 결과는 7차 교육과정에서 학년별 국어 교 과서에 포함된 순수 관용어 출현 빈도가 $2,3,4,5$ 학년에 비해 6학 년에서 두드러지게 증가한다는 보고(Lee, 2004)와도 일치한다. 또 한 6학년 2학기 국어 과목의 단원 목표(Appendix 1) 중 하나가 “관 용 표현을 사용하면 좋은 점을 알고 관용 표현을 쓸 수 있다”라는 점은 이러한 결과가 교육과정의 영향일 수 있음을 시사한다. 그러 나 본 연구가 동일한 아동에 대해 하루의 간격을 두고 작성토록 한 두 가지 유형의 담화를 분석하였다는 점을 고려할 때, 6 학년에서의 높은 관용어 비율이 왜 유독 이야기담화에서 두드러졌는지 숙고해 볼 필요가 있다. 아동들이 '내 친구’를 묘사하기 위해서는 친구를 떠올리며 처음부터 스스로의 언어로 글을 작성해야 하지만, "백설 공주'의 경우 이미 책으로 읽었거나 부모가 읽어주는 동화를 들으 면서 풍부한 문학적 표현에 노출된 경험을 갖고 있을 것이다. 이와 같이 이미 읽었거나 들어 본 적이 있는 '백설공주를 작성할 때 아 동들은 앞서 경험했던 문학적 표현을 사용하려는 경향을 보일 수 있다. 이때, 아동들은 이야기를 듣거나 읽으면서 경험했던 것과 동 일한 표현이 아니더라도 좀 더 문학적으로 표현하려는 경향을 보일 수 있다. 이러한 결과는 이야기담화가 학령기 아동의 관용어 중재 시 효율성이 높은 담화유형일 수 있음을 시사한다.

직유, 은유, 관용어 표현에 대한 이와 같은 연구 결과, 전체적인 비유언어 비율은 두 담화유형에서 유사하였다. 그러나 묘사담화에 서는 직유 비율이 학년이 올라가면서 두드러지게 증가한 반면, 이 야기담화에서는 직유 표현 비율이 학년에 따라 오히려 감소하면서 관용어 비율이 두드러지게 높아지는 경향을 보였다. 이러한 결과에 근거할 때, 글쓰기 장르에 따라 문체가 달라지고, 문체에 따라 비유 언어 사용 양상이 달라질 것이라는 본 연구의 가설이 전체적인 비
유언어 사용 비율보다는 담화유형에 따라 선호되는 비유언어 유형 에 의해 실현된다는 것을 알 수 있다. 이는 언어발달이 지체된 학령 기 아동의 언어 중재 시 비유언어 하위 유형에 따라 서로 다른 담화 유형을 활용할 필요가 있음을 시사한다. 즉, 직유의 이해나 표현 중 재 시에는 동물이나 사람, 장소 등에 대한 다양한 수준의 묘사담화 를 활용하고, 관용어는 언어 능력 수준을 고려한 이야기담화를 활 용하는 것이 효과적일 수 있다.

본 연구는 비유언어 사용 비율이 담화길이나 어휘다양도와 어떠 한 상관관계를 보이는지에 대해서도 살펴보았다. 분석 결과, 직유, 은유, 관용어의 비율은 담화길이와는 유의한 상관관계를 보이지 않았으나 어휘다양도와는 높은 상관관계를 보였다. 이러한 결과는 단순히 글의 길이가 길어지고 어휘수가 증가한다고 해서 아동의 비 유 표현 능력이 자연스럽게 따라오는 것이 아니며 다양한 어휘를 사용할 줄 알수록 비유언어 사용 능력도 높아진다는 것을 의미한 다. 이는 비유언어가 어휘력 확장에 도움이 된다는 Dickson (2010) 의 주장을 지지하는 것이다. 또한 이해 차원에서 수용어휘 능력이 관용어 이해에 대한 예측 인자라는 선행연구(Shin, 2015)와도 맥을 같이하는 것이다. 이러한 결과는 비유언어 중재 시 어휘관계를 연 계한 활동이 효과적일 수 있음을 시사한다.

이와 같이 본 연구는 학령기 아동의 비유언어 사용 비율 및 담화 요소와의 상관관계를 통하여 몇 가지 언어발달적 의미와 임상적 시 사점을 제시할 수 있었다. 이러한 결과는 일반 아동의 비유언어 발 달에 대한 실제적 정보를 제공할 수 있으며 학령기 교육과정에도 반영될 수 있을 것이다. 또한 언어발달이 지체된 학령기 아동에 대 한 비유언어 중재 시 비유언어 유형에 따라 담화유형을 선정할 수 있도록 기초 정보를 제공할 수 있을 것이다. 그러나 본 연구가 쓰기 검사 과정에서 순서효과를 통제하지 않은 점은 제한점이 될 수 있 다. 본 연구의 결과가 일관성 있는 정보로 채택되기 위해서는, 향후 순서효과를 엄격하게 제한하면서 동일한 담화유형에 대한 추가 연 구를 통해 유사한 결과가 나타나는지 확인할 필요가 있다. 아울러 좀더 다양한 담화유형으로 범위를 확장하고, 표현 능력의 또 다른 축이 되는 말하기에서의 비유언어 사용을 분석하여 쓰기에서의 결 과와 비교할 필요가 있다.

\section{REFERENCES}

Bae, H. S. (2016a). A study of story grammar and cohesive markers of schoolaged children depending on narrative discourse writing. Journal of SpeechLanguage and Hearing Disorders, 25, 43-60.

Bae, H. S. (2016b). Characteristics of semantic, morphological, and syntactic 
development in descriptive writing of school-aged children. Korean Journal of Linguistics, 41, 407-429.

Billow, R. M. (1975). A cognitive developmental study of metaphor comprehension. Developmental Psychology, 11, 415-423.

Byun, Y. H., \& Choi, K. S. (2000). Development of metaphor comprehension depending on contextual clue and metaphor type. The Korean Journal of Human Development, 7, 49-64.

Cain, K., Oakhill, J., \& Lemmon, K. (2005). The relation between children's reading comprehension level and their comprehension of idioms. Journal of Experimental Child Psychology, 90, 65-87.

Cain, K., Towse, A. S., \& Knight, R. S. (2009). The development of idiom comprehension: An investigation of semantic and contextual processing skills. Journal of experimental child psychology, 102, 280-298.

Choi, J. H. (2010). Study on metaphor and metonymy in Korean idioms. Seoul: Hyean Publishing.

Chung, H. S. (2002). A study on elementary school students' understanding of indirect expressions: centered on metaphors and proverbs. Korean Language and Literature, 132, 89-119.

Colston, H. L., \& Kuiper, M. S. (2002). Figurative language development research and popular children's literature: why we should know, "Where the Wild Things Are". Metaphor and Symbol, 17, 27-43.

Dickson, V. M. (2010). The transfer and sustainability of a school-wide writing program: year 2 (Doctoral dissertation). North Texas University, Denton, TX, USA.

Hong, Y., \& Yim, D. (2014). The relationship between working memory and metaphor comprehension in school-age children with specific language impairments. Communication Sciences \& Disorders, 19, 191-198.

Hunt, K. (1965). Grammatical structures written at three grade levels. Champaign, IL, USA: NCTE.

Hyun, H. S., Kim, Y. T., \& Lim, D. S. (2011). Comparison of idiom comprehension ability of school-aged poor reading comprehenders and typically developing peers: the role of context, transparency and familiarity. Korean Journal of Special Education, 46, 173-195.

Jakobson, R. (1973). Essais de linguistique générale. Paris: Les Editions de Minuit. Jeong, J. A. (2012). A comparative study on simile comprehension of mild mental retardation and normal children (Master's thesis). Dankook University, Seoul, Korea.

Kim, H. N. (2012). Comparison of idiom comprehension ability by context and non-context (Master's thesis). Dankook University, Seoul, Korea.

Kim, M. M. (2002). The analysis on the developmental tendency of understand- ing of metaphors (Master's thesis). The Catholic University of Korea, Seoul, Korea.

Kim, M. N., \& Jeon, H. S. (2013). Characteristics of simile comprehension according to the age of preschool children. Journal of Speech \& Hearing Disorders, 22, 81-102.

Kim, Y. I., Nam, Y. S., \& Kwon, S. W. (2012). The effect of idiom reading instruction by illustrated configurations on the idiom understanding of hearing impairment students with cochlear implants. Journal of Speech \& Hearing Disorders, 21, 103-124.

Kuczaj, S. A., \& McClain, L. (1984). Of hawks and moozes: the fantasy narratives produced by a young child. In S. A. Kuczaj (Ed.), Discourse development: progress in cognitive development research (pp. 125-146). New York, NY: Springer.

Lakoff, G., \& Johnson, M. (2003). Metaphors we live by. Chicago, IL: University of Chicago Press.

Lee, D. H., Ko, S. H., \& Hwang, M. (2014). Characteristics of idiom's comprehension in school-aged children with Asperger's syndrome. Journal of Speech \& Hearing Disorders, 23, 105-112.

Lee, H. J., \& Kim, M. (2015). The correlation between metaphor comprehension and reading comprehension of poor readers in 4-6 grades. Communication Sciences \& Disorders, 20, 331-343.

Lee, J. M. (2011). A study on the aspects of metaphorical expressions of elementary school children (Master's thesis). Gyeongin National University of Education, Incheon, Korea.

Lee, K. S. (2004). A study of the teaching method about idioms of Korean language in elementary schools (Doctoral dissertation). Gyeongin National University of Education, Incheon, Korea.

Lee, S. I., Bae, H. S., \& Lee, Y. (2016). Comprehension abilities of idioms according to semantic types and familiarity in school-aged children with high-functioning autism spectrum disorder. Communication Sciences \& Disorders, 21, 230-243.

Lim, J. A. (2010). The comprehension of figurative meaning in ADHD children with and without language impairment. Korean Journal of Communication Disorders, 15, 307-320.

MacSaveny, T. (2010). Towards a description of descriptive discourse. GIALens, 3, 1-5.

Moon, K. H. (1996). A study of idiomatic expressions in Korean (Doctoral dissertation). Seoul University, Seoul, Korea.

Naylor, L., \& Van Herwegen, J. (2012). The production of figurative language in typically developing children and Williams Syndrome. Research in De- 
velopmental Disabilities, 33, 711-716.

Nippold, M. A. (1985). Comprehension of figurative language in youth. Topics in Language Disorders, 5, 1-20.

Nippold, M. A., \& Haq, F. S. (1996). Proverb comprehension in youth: the role of concreteness and familiarity. Journal of Speech, Language, and Hearing Research, 39, 166-176.

Nippold, M. A., \& Taylor, C. L. (1995). Idiom understanding in youth: further examination of familiarity and transparency. Journal of Speech, Language, and Hearing Research, 38, 426-433.

Nippold, M. A., Taylor, C. L., \& Baker, J. M. (1996). Idiom understanding in Australian youth: a cross-cultural comparison. Journal of Speech, Language, and Hearing Research, 39, 442-447.

Pae, S. Y., Kwon Y. J., \& Jin, Y. S. (2009). Korean narrative assessment. Paper presented at the Workshop of The Korean Academy of Speech-Language Pathology and Audiology, Seoul, Korea.

Park, Y. S. (2000). Study on metaphor in Korean language. Seoul: Korea University Press.

Reed, V. A. (2012). An introduction to children with language disorders. Boston, MA: Pearson.

Seidenberg, P. L., \& Bernstein, D. K. (1988). Metaphor comprehension and performance on metaphor-related language tasks: a comparison of good and poor readers. Remedial and Special Education, 9, 39-45.

Shin, H. N. (2015). A study of the understanding and related factors of idioms in third and fifth grade students. Journal of Speech-Language \& Hearing Disorders, 24, 135-145.
Siltanen, S. A. (1990). Effects of explicitness on children's metaphor comprehension. Metaphor and Symbol, 5, 1-20.

Song, S. H. (2012). Comparative study on the smile comprehension ability between poor comprehenders and general students in the third-fourth grade of elementary school (Master's thesis). Dankook University, Seoul, Korea.

Sweet, J. A. (1974). An analysis of the writing of elementary children, grades four through six, to determine the relationship between specified genre and the development and use of figurative language (Doctoral dissertation). Indiana University, Bloomington, IN.

Um, G. Y. (2014). A comparative study on the metaphor and simile comprehension ability in poor comprehenders and general children (Master's thesis). Daegu University, Daegu, Korea.

Van Kleeck, A. (1994). Metalinguistic development. In G. P. Wallach and K. G. Butler (Eds.), Language learning disabilities in school-age children and adolescents: some principles and applications (pp. 53-98). Boston, MA: Allyn \& Bacon.

Vogindroukas, I., \& Zikopoulou, O. (2011). Idiom understanding in people with Asperger syndrome/high functioning autism. Revista da Sociedade Brasileira de Fonoaudiologia, 16, 390-395.

Winner, E., Rosenstiel, A. K., \& Gardner, H. (1976). The development of metaphoric understanding. Developmental Psychology, 12, 289-297.

Yi, D., Hwang, M., \& Lim, J. A. (2013). Proverb comprehension in children with Asperger's disorder: the role of transparency. Communication Sciences \& Disorders, 18, 288-296. 
Hee-Sook Bae, et al. • Figurative Expressions of School-Aged Children

Appendix 1. Unit test results of participants (Korean language)

\begin{tabular}{|c|c|c|c|c|c|}
\hline Grade & Eval. & $70-80$ & $80-90$ & $90-100$ & Learning goals of each unit \\
\hline \multirow[t]{2}{*}{2} & 1st T & 1 & 5 & 18 & 글을 읽고 중요한 내용을 알아봅시다. 그리고 내용이 잘 드러나게 설명하는 글을 써 봅시다. \\
\hline & 2nd T & 1 & 6 & 17 & 낱말과 낱말의 의미 관계를 알고 활용할 수 있다 \\
\hline \multirow[t]{2}{*}{4} & 1st T & 3 & 5 & 16 & 글을 읽고 자신의 생각을 다양한 방법으로 표현하여 봅시다. \\
\hline & 2nd T & 3 & 9 & 12 & 작품 속 인물, 사건, 배경에 대해 알고 대강의 내용을 간추릴 수 있다. \\
\hline \multirow[t]{2}{*}{6} & 1st T & 4 & 13 & 7 & 글을 읽고 글쓴이의 관점을 알아보기. 자신의 관점이 드러나도록 글쓰기. \\
\hline & 2nd T & 9 & 7 & 8 & 관용 표현을 사용하면 좋은 점을 알고 관용 표현을 쓸 수 있다. \\
\hline
\end{tabular}

Appendix 2. Scoring examples of figurative expressions

\begin{tabular}{|c|c|c|c|c|}
\hline Types & Samples & Simile & Metaphor & Idiom \\
\hline \multirow[t]{6}{*}{ Descriptive } & 내 친구는 처음 만났을 때부터 가족같이 친근합니다. & 1 & 0 & 0 \\
\hline & 까만 조약돌같이 반짝거리는 동그란 눈 & 1 & 0 & 0 \\
\hline & 내 친구는 눈이 반달이고 얼굴이 삼각형이다. & 0 & 2 & 0 \\
\hline & 요즘 내 친구는 마술에 빠져 있습니다. & 0 & 1 & 0 \\
\hline & 하지만 OO는 입이 무겁습니다. & 0 & 0 & 1 \\
\hline & 함부로 덤비다간 큰 코 다친다. & 0 & 0 & 1 \\
\hline \multirow[t]{6}{*}{ Narrative } & 공주는 눈같이 하얀 피부를 가지고 & 1 & 0 & 0 \\
\hline & 그녀의 피처럼 붉은 입술을 가진 공주로 자라나라고 & 1 & 0 & 0 \\
\hline & 백설공주는 마음이 천사였어요. & 0 & 1 & 0 \\
\hline & 백설공주가 깊은 잠에서 갑자기 살아났어요. & 0 & 1 & 0 \\
\hline & 하지만 마녀의 계획은 들통이 나고 말았어요. & 0 & 0 & 1 \\
\hline & 성대한 결혼식으로 이야기가 막을 내린다 & 0 & 0 & 1 \\
\hline
\end{tabular}




\section{국문초록}

\section{학령기 아동의 쓰기를 통해 살펴본 담화 유형에 따른 비유 표현 발달 양상 배희숙 ${ }^{1} \cdot$ 박성희 ${ }^{2}$ \\ '우송대학교 언어치료청각재활학과, ${ }^{2}$ 전북대학교병원 재활의학과}

배경 및 목적: 본 연구는 학령기 아동의 글쓰기에 나타난 비유언어(직유, 은유, 관용어)가 담화유형(묘사담화, 이야기담화) 및 학년(2, 4, 6)에 따라 어떠한 사용 양상을 보이는지, 비유언어의 사용 비율은 담화길이(T-unit, NTW)나 어휘다양도(NDW, MLT-dw)와 어떠한 상관관계를 보이는지 파악하고자 하였다. 방법: 서울 소재 초등학교에 다니는 72명의 일반 아동을 대상으로 '내 친구’와 ‘백설공주’를 주제로 쓰기검사를 실시하여 묘사담화와 이야기담화 자료를 수집하였다. 대상 아동이 담화 쓰기에서 사용한 비유언어를 분석하기 위 하여 직유, 은유, 관용어 빈도를 측정한 후 T-unit에 대한 비율로 분석하였고, 담화길이는 T-unit과 NTW로, 어휘다양도는 NDW와 Tunit에 대한 NDW의 비율인 MLT-dw (NDW/T-unit)로 측정하였다. 결과: 학령기 아동의 담화 쓰기에서 비유언어 사용 비율은 전반적 으로 학년이 올라감에 따라 증가하였으나, 비유언어 하위 유형에 따라 그 양상은 다양하게 나타났다. 또한 상관관계 분석에서 비유 표 현은 담화길이와는 달리 어휘다양도와 유의한 정적 상관관계를 보였다. 논의 및 결론: 본 연구의 결과는 학령기 비유언어 평가 및 중재 시 담화유형과 비유유형을 모두 고려할 필요가 있으며 비유언어 중재가 어휘 의미관계 확장에 도움이 될 수 있음을 시사한다.

핵심어: 비유 표현, 비유언어 발달, 학령기 아동, 묘사담화, 이야기담화.

\section{참고문헌}

김명미(2002). 은유 이해력의 발달 경향 분석.가톨릭대학교 대학원 석사학위논문.

김미나, 전희숙(2013).3세와 5세 아동의 연령에 따른 직유 이해 특성. 언어치료연구, 22, 81-102.

김영익, 남윤석, 권순우(2012). 삽화 구성을 통한 관용어 읽기지도가 인공와우 착용 청각장애학생의 관용어 이해와 쓰기에 미치는 효과. 언어치료연

구, 21, 103-124.

김하늬(2012). 읽기이해부진 아동과 일반아동의 문맥 유무에 따른 관용어 이해능력 비교. 단국대학교 대학원 석사학위논문.

문금현(1996). 국어의 관용표현 연구. 서울대학교 대학원 박사학위논문.

박영순(2000). 한국어은유 연구. 서울: 고려대학교출판부.

배소영, 권유진, 진연선(2009). 이야기 평가. 한국언어청각임상학회 워크숍.

배희숙(2016a). 이야기담화 쓰기를 통한 학령기 아동의 이야기 문법 및 결속표지 연구. 언어치료연구, 25, 43-60.

배희숙(2016b). 학령기 아동의 묘사적 글쓰기에 나타난 의미론적, 형태론적, 통사론적 발달 특성 분석. 언어, 41, 407-429.

변윤희, 최경숙(2000). 문맥적 단서와은유의 종류에 따른 아동의 은유 이해의 발달. 인간발달연구, 7, 49-64.

송순호(2012). 초등학교 3,4학년 읽기이해 부진 학생과 일반학생의 직유이해 능력 비교. 단국대학교 대학원 석사학위논문.

신후남(2015). 초등학교 3, 5학년의 관용어 이해 및 관련요인에 대한 연구. 언어치료연구, 24, 135-145.

엄가연(2014). 읽기학습부진 아동과 일반아동의 은유, 직유 이해 능력 비교. 대구대학교 대학원 석사학위논문.

이광순(2004). 초등 국어교육에서의 관용표현 지도 방안 연구. 경인교육대학교 대학원 박사학위논문.

이다미, 황민아, 임종아(2013). 아스퍼거 아동의 속담 이해 특성. 언어청각장애연구, 18, 288-296.

이다희, 고선희, 황민아(2014). 학령기 아스퍼거 아동의 관용어 이해 특성. 언어치료연구, 23, 105-112.

이송이, 배희숙, 이영미(2016). 관용어 의미 유형과 친숙도에 따른 학령기 고기능 자폐스펙트럼장애 아동의 관용어 이해 능력. 언어청각장애연구, 21,

230-243.

이정민(2011). 초등학생의 은유 표현 양상에 관한 연구. 경인교육대학교 대학원 석사학위논문. 
이현정, 김미배(2015). 4-6학년 읽기부진아동의 은유이해능력과 읽기이해능력의 상관관계. 언어청각장애연구, 20, 331-343.

임종아(2010). 주의력결핍 과잉행동장애(ADHD)아동의 비유 의미 인식. 언어청각장애연구, 15, 307-320.

정지아(2012). 경도지적장애아동과 일반아동의 직유 이해 능력 비교. 단국대학교 대학원 석사학위논문.

정혜승(2002). 초등학생의 간접적 표현의 이해에 관한 연구: 은유와 속담을 중심으로. 국어국문학, 132, 89-119.

최지훈(2010). 한국어 관용구의 은유 환유 연구. 서울: 혜안.

현혜숙, 김영태, 임동선(2011). 읽기이해부진 아동의 관용어 유형 및 과제제시 방법에 따른 관용어 이해 능력. 특수교육학연구, 46, 173-195.

홍영주, 임동선(2014). 학령기 단순언어장애아동의 작업기억과 은유 이해능력 간의 관계: 언어성 및 비언어성 과제를 중심으로. 언어청각장애연구,

19, 191-198. 